\title{
Phospholipid-Transporting ATPase ABCA1
}

National Cancer Institute

\section{Source}

National Cancer Institute. Phospholipid-Transporting AT Pase ABCA1. NCI Thesaurus.

Code C116410.

ATP-binding cassette sub-family A member 1 (2261 aa, $254 \mathrm{kDa}$ ) is encoded by the human ABCA1 gene. This protein plays a role in intracellular cholesterol transport. 